willingness, in the overall discourse of elite education, to suggest meaningful alternatives. As the second chapter of this study shows in greater detail, sociological studies and journalistic investigations of elite education all find fault with the status quo of the meritocracy, but simultaneously operate entirely within its ideological framework. Their suggestions for reform, then, are geared toward improving the meritocracy by making it more just and less susceptible to the undue influence of capital and power. There is very little awareness in this critical landscape of the systemic flaws and inconsistencies of the ideology of meritocracy-flaws and inconsistencies that were so obvious to Michael Young when he coined the term. A recent and paradigmatic case in point is Lani Guinier's book The Tyranny of the Meritocracy: Democratizing Higher Education in America (2015). Its title suggests an awareness of the pitfalls of meritocratic structures and a commitment to rethinking and reforming the educational system in accordance with democratic principles. Guinier's central suggestion, however, is simply to change the definition of merit from what she calls a 'testocratic' one-test scores, grades, and other measures of individual competition-to a 'democratic' one: "a student's capacity to collaborate and think creatively" (xiii). "If we are going to have a 'meritocracy'-which really just means 'rule by merit'," Guinier writes, "then we need a better conception of what now constitutes merit in our society versus what it should be" (xi). Despite the implications of its title, then, Guinier's book likewise operates squarely within the ideological framework of the meritocracy. There surely are in the United States educators, researchers, or other commentators who are genuinely critical of the very idea of the meritocracy and attempt to think of alternative systems instead of merely changing the definition of merit. In the discourse of elite education, however, these voices are not heard.

\title{
5. 'A Touchy Subject'? Class and Elite Education
}

As the previous sections have shown, eliteness is an elusive quality that the discourse of elite education does not always make explicit, even though it is at the heart of its epistemological practices. Merit, by contrast, is a concept with strong legitimatory potentials and, as such, is frequently invoked, despite the lack of agreement on its meaning(s). The constitution and operation of both notions, as has become clear time and again, depends strongly on different forms of capital. The production of meritorious-i.e. "measurably 
talented," as Stevens puts it (22)—individuals, for instance, costs money, warrants connections, and requires specific kinds of knowledge. Eliteness, too, is expensive, as indicated by the impressive endowments and spending patterns of those institutions commonly thought of as 'elite'. Their exclusiveness likewise depends upon their social and cultural capital-access to famous and influential people, or ties to other institutions, for example.

This leads us to the third and last category I want to introduce in this chapter: class. It is something of a truism to point to the conflicted, ambiguous, and contradictory ways in which class is talked about-or not talked about-in the United States. Americans, critics and commentators seem to agree, range somewhere between willfully ignorant and grossly negligent when it comes to the issue of socio-economic stratification. In his 1980 book Inequality in an Age of Decline, Sociologist Paul Blumberg argues that "[w]ithin the framework of the American tradition of classlessness, social class is America's forbidden thought, its dirty little secret that cannot be expressed openly and directly but emerges via subterranean paths and masquerade" (53). Paul Fussell complains in his introduction to Class: A Guide through the American Status System (1983) that whenever he talked about his research on class, people responded as if he "had said, 'I am working on a book urging the beating to death of baby whales using the dead bodies of baby seals" (15). A deep sense of discomfort thus appears to permeate the American imagination with regard to the issue of class and status.

Interestingly, however, these observations do not hold true in the context of the contemporary discourse of elite education. In fact, in this discursive space, class plays an increasingly prominent role, albeit a rather undertheorized one. All three epistemological paradigms I examine in this study-the critical-analytical, the affirmative, and the imaginative-engage with socioeconomic factors in one way or another. In the sociological and journalistic texts that form the core of the following chapter, class is one, if not the primary analytical category, and its examination is closely linked to the expectation that elite educational institutions serve as engines of social mobility. In the self-representational materials-promotional brochures, videos, and other content published by Princeton University-class-related policies and achievements are placed quite prominently, even though the treatment of socio-economic factors remains selective and incomplete. Fictional texts set in the elite educational space likewise conspicuously prioritize socio-economic stratification as the central issue informing the experiences of campus novel protagonists. The treatment of class in the discourse of elite education thus 
not only demonstrates that class is, in fact, very much talked about in the United States, but also testifies to the different dimensions on which class operates: economic and material, cultural and ideological, psychological and physical.

\section{Approaching Class in the Discourse of Elite Education}

This relative openness notwithstanding, however, class poses a problem for the discourse of elite education. The strong correlation between socio-economic background and educational achievement does not resonate well with American self-descriptions as the land of fairness and opportunity for all, and the various efforts made to alleviate this correlation have to contend with the fact that class, due to its multilayered nature, is not easily integrated into existing patterns of such alleviation. A case in point is the 'diversity paradigm', discussed in greater detail in Chapter 3, which serves to recognize, affirm, and celebrate difference. Class difference, however, does not seem to be something Americans want to recognize, much less claim in an affirmative manner-countless studies and polls tell us that most Americans cling to the belief of belonging to one large middle class. The American imagination is informed by a strong desire for socio-economic structuration not to matter, nor even to be acknowledged. The diversity paradigm thus does not resonate well with class, as Walter Benn Michaels argues:

[T] he kind of diversity produced by a larger number of poor students isn't exactly the sort of thing a college can plausibly celebrate-no poor people's history month, no special 'theme' dormitories (i.e., no Poor House alongside Latino House or Asian House) and no special reunions for poor alumni. Indeed, the whole point of going to Harvard, from the standpoint of the poor, would be to stop being poor, whereas Asian Americans, African Americans, Latinos, et cetera, presumably don't want to stop being Asian American, African American, et cetera. (2006: 89)

Rita Felski explains the difficulty of combining class analysis and identity politics by pointing out that "class is essentially, rather than contingently, a hierarchical concept" (42). Class politics, she argues, "is ultimately concerned with overcoming or at least lessening class differences, not with affirming and celebrating them" (ibid.). But is this true? First, race and gender-in a society that so obviously values whiteness and masculinity-are de facto also hierarchical concepts and would lose their meaning if the hierarchies were dissolved. The 
mere fact of distinguishing between two or more identity positions arguably always implies a hierarchical rather than egalitarian relationship-in practice, at least, if not in theory. And second, depending on how one conceptualizes 'class differences', related politics do not necessarily have to aim at lessening or overcoming them. Not everyone wants to be like the rich, nor even be rich, for that matter.

In the following, I outline my own understanding of class, which is informed, by and large, by the work of Pierre Bourdieu, Gavin Jones, and Rita Felski. It is important to note here that while the following observations inform my own thinking about class as a complex and multidimensional construct, this complexity is not always necessarily reflected in the discourse of elite education. In fact, as I have already indicated above, the discourse itself often produces an understanding of class that is far more simplistic and reductive than that of class theorists.

In the discourse of elite education, class is primarily conceptualized as family income. The class-related issues that are discussed most frequently are affordability, particularly in light of steadily rising tuition costs, and access, primarily in light of the competitive advantage enjoyed by applicants from affluent families. The critical-analytical studies discussed in the following chapter agree that class 'should not matter' in elite college admissions, but that it unfortunately does; one of the studies' central demands is that elite institutions stop privileging affluence and start implementing programs to help low-income applicants and students. The self-representational materials discussed in the third chapter oscillate between affirmative and evasive positions toward class: On the one hand, universities try to include class in the 'diversity paradigm', and on the other hand they present information in such a way as to suggest a class diversity that does not, in fact, exist. Fictional narratives, as the fourth chapter shows in greater detail, insist that class matters, in various ways, and their conceptualization of class overall comes closest to my own. At the same time, however, many campus novels structurally reproduce the illusion of class diversity at elite institutions, as Michaels points out (2007: 96).

In order to approach class, I ask three related sets of questions. First, what is class? Which factors determine one's class position? Second, does class exist in practice or is it merely a theoretical construct? Third, how does class inform an individual's identity? Is it contingent or permanent? What role do social mobility and intersectionality play? 
In The American Class Structure in an Age of Growing Inequality ( $9^{\text {th }}$ edition, 2015), Dennis Gilbert defines social classes "as groups of families, more or less equal in rank and differentiated from other people above or below them with regard to characteristics such as occupation, income, wealth, and prestige" (11). Paul Fussell points out that despite their reluctance to acknowledge class differences, Americans have, over time, developed an elaborate system of social and cultural distinctions that may offer clues about someone's class position (15). Consumption patterns, behaviors, tastes, desires-in short, everything a person thinks, does, wears, and desires can be related to his or her position in the income distribution. Thus, while Gilbert's definition sounds straightforward enough, class remains a contested and slippery concept, fraught with a variety of tensions. Whenever the importance of cultural factors in processes of socio-economic stratification are emphasized, one enters Bourdieusian territory. According to Bourdieu, to talk about class means to talk about an individual's position in social space. Classes are "categories of people who occupy positions within a field [...] which are, in terms of the topology of the field, similar or close to each other" (Jenkins 54). An individual's position is determined by her "portfolio of capital" (Grenfell 88), which is constituted by economic, cultural, social, and symbolic resources. Individuals who are close to each other in social space "are inclined to develop similar lifestyles, outlooks, dispositions and a tacit sense of their place in the world" (Grenfell 93). Bourdieu calls this set of attitudes and behaviors the habitus. Insisting on the importance of cultural and psychological factors, and stressing the role of taste and embodiment, Bourdieu moves away from the Marxist conception of class as a narrowly economic and materialist category determined by the individual's position with regard to the means of production. "Forms of symbolic and social accumulation and differentiation" (Swartz 147) form a crucial part of class relations and politics, which are always informed by "the material conditions of existence" (Bourdieu 1986: 106), but are not necessarily determined by them.

Felski similarly explains that her approach focuses "on the psychic as well as the social, semiotics as much as economics" (34). Class, then, manifests itself in wealth and different sources of income, but also in occupation, prestige, association and socialization, in behaviors, patterns of consumption, matters of style and taste. This multiplicity is what Gavin Jones calls the "peculiar dialectics" of class, namely the oscillation between "material and nonmaterial, objective and subjective criteria" (3). Situated at the intersection of discourse, practice, and the body, class thus includes the "materiality of 
need" - and, one might add, that of abundance-as well as the "nonmaterial areas of psychology, emotion and culture, [...] moving away from the absolute and objective toward the relative, the ideological, and the ethical" (ibid.).

But are these positions in social space felt and recognized by the people who inhabit them or are they merely constructs used by social science researchers? Bourdieu insists "on a sharp distinction between social classes as scientific constructs and social classes as real mobilized social groups" (Swartz 148). This distinction, as Jenkins points out, owes "no small debt to Marx's distinction between the class-in-itself (objectively defined) and the class-for-itself (subjective class consciousness)" (54). In the discourse of elite education, class remains for the most part a theoretical construct employed by sociologists, admissions officers, advertisers, and novelists. There is little evidence, of yet, of any meaningful efforts of class mobilizations. The difficulty of coming to terms with one's class position, the difficulty of developing class consciousness is described poignantly in Curtis Sittenfeld's novel Prep, which I discuss in detail in the last chapter of this study.

In the American cultural imagination, one of the dominant ways of framing class is through the notion of mobility. In the realm of fiction and storytelling, in particular, class is rarely portrayed as permanent or fixed, but rather as always in flux and quite often as upwardly mobile. To think about class in terms of mobility raises questions about its "ontological status [...] as a matter of personhood," as Felski puts it (38). How strongly does one's class position influence one's sense of identity? And if one's class position changes, does one's identity change as well, and in what ways? Unlike race or gender, which "often mark identity inescapably," as Felski points out (ibid.), class boundaries seem porous and comparatively easy to transcend. "If one has become uppermiddle-class as a result of social mobility," Felski argues, "then one really is upper-middle-class-class being, in one sense, nothing more than the sum of its material manifestations" (ibid.). In other ways, however, one's original class identity might very well linger, and one might experience difficulties in adjusting to one's new position. To look at class through the lens of mobility thus demonstrates the importance of conceptualizing it as a multidimensional construct: In terms of its economic foundations, such as income or wealth, class has to be seen as contingent, but in terms of its cultural and psychological reverberations, it might be much more permanent.

In addition to this multidimensionality, class also has to be conceptualized as an intersectional category. The term 'intersectionality' was coined by critical race scholar and legal theorist Kimberlé Crenshaw (1989) in order to illustrate 
the multilayered oppression faced by women of color due to a convergence of racism, sexism, and classism (Smooth 32). Crenshaw describes the concept as follows:

Consider an analogy to traffic in an intersection, coming and going in all four directions. Discrimination, like traffic through an intersection, may flow in one direction, and it may flow in another. If an accident happens in an intersection, it can be caused by cars traveling from any number of directions, sometimes from all of them. Similarly, if a black woman is harmed because she is in the intersection, her injury would result from sex discrimination or race discrimination. (149)

A person's class position, as well as her class identity and the way she is perceived by others, are thus informed by other identity markers, such as gender, race, ethnicity, age, (dis)ability, sexuality, religion, and nationality. In the discourse of elite education, intersectionality is an important factor to keep in mind, because awareness of it can change the ways in which we interpret certain kinds of information, particularly statistical data. When Princeton University, for instance, states in one of its promotional brochures that its student body includes 42 percent Americans with minority background, this does not mean, as many might assume, that these students are from lowincome families in the inner city. 'Minority background', in this context, is a purely racial/ethnic marker, and neglects socio-economic status. By the same token, while the university's statement that 60 percent of its students receive financial aid seems to indicate a solid degree of socio-economic diversity on campus, the opposite is the case. In fact, the median family income of a student at Princeton is $\$ 186,100$ (more than three times as high as the median household income in the United States, which in 2015 was $\$ 56,516$ ). 72 percent of students come from the top 20 percent of the income distribution, and only 2.2 percent from the bottom 20 percent. It is quite important, then, to keep in mind the multiple levels on which class operates, manifests itself, becomes visible, or is obscured, as well as the ways in which it interacts with and is informed by other social and cultural categories.

\section{Class and Merit}

The discourse of elite education tries to solve the problem of class in part by emphasizing merit as an allegedly class-neutral category. The topos of merit generates images of legitimacy and fair competition, and thus allows the dis- 
course to frame stratification as something just, inevitable, and even desirable. Seemingly stable, ahistorical, and easily determined via tests and examinations, merit eclipses any relation between the elite educational space and class. It is posited as the opposite of hereditary privilege and constructed as a category somehow exempt from socio-economic factors-if someone is judged on the basis of merit, the reasoning goes, she is precisely not judged on the basis of class. In the fantasy of the meritocracy, there is no room for economics or the complexities of capital; there is one the deserving and the un-deserving.

The way the topos of merit legitimizes existing structures is illustrated poignantly by the example of Hunter College High School in Manhattan. Hunter is perhaps the most purely meritocratic educational institution in the United States: It is public and free of tuition, open to students from all over New York City, and admission is based on a single test that students take in the sixth grade. Hunter's mission statement explains that "[o]ur schools strive to reflect the city they serve by admitting and educating a population of students who are culturally, socio-economically, and ethnically diverse. We seek to serve as a model for combining excellence and equity, serving as a catalyst for change in New York City and the nation" ("Mission Statement"). Christopher Hayes, himself a Hunter alumnus, talks at length about the school in his book about the failures of the American elites. Despite the school's professed mission, he points out, "Hunter has never had a student body that matched the demographic composition of the city in which it resides" (36). The entering class of 2009, for instance, was only three percent black and one percent Hispanic (ibid.), even though the population of New York City was 25 percent black and 28 percent Hispanic in 2010. In large parts, this is due to the emergence of a professionalized support industry geared toward preparing applicants for the Hunter admissions test-the more money parents are willing and able to spend on tutors, summer classes, and study materials, the more likely their kids are to get in. Hayes goes on to quote from Hunter student Justin Hudson's 2010 commencement address, which caused something of a scandal in the Hunter community:

More than happiness, relief, fear, or sadness, I feel guilty. I feel guilty because I don't deserve any of this. And neither do any of you. We received an outstanding education at no charge based solely on our performance on a test we took when we were eleven-year-olds (...). We received superior teachers and additional resources based on our status as 'gifted', while kids who nat- 
urally needed those resources much more than us wallowed in the mire of a broken system. And now, we stand on the precipice of our lives, in control of our lives, based purely and simply on luck and circumstance. (...) Hunter is perpetuating a system in which children, who contain unbridled and untapped intellect and creativity, are discarded like refuse. And we have the audacity to say they deserved it, because we're smarter than them. (quoted in Hayes 33)

Hudson's speech illustrates the fragility of arguments in support of meritocratic structures by demonstrating that merit is not a category devoid of connections with class and capital. A somewhat similar point is made by Michaels, who argues that affirmative action programs do not contradict meritocratic principles, as their critics often claim, but that they, in fact, produce "the illusion that we actually have a meritocracy" (2007: 85, emphasis in the original). According to Michaels, the rhetoric of affirmative action eclipses socio-economic concerns: "Race-based affirmative action [...] is a kind of collective bribe rich people pay themselves for ignoring economic inequality. The fact (and it is a fact) that it doesn't help to be white to get into Harvard replaces the much more fundamental fact that it does help to be rich and that it's virtually essential not to be poor" (2007: 86). ${ }^{5}$

The individualistic, merit-based legitimation of one's claim to the elite educational space can also be found in a short video production of the $I$, too, am Harvard project mentioned above. In the clip, students talk about their experiences of race and racism on campus and about their desire to feel validated as part of Harvard's community. Toward the end, a young woman concludes: "To the doubters: everyone here is incredibly brilliant. Everyone here worked incredibly hard" (quoted in Bean). Again, merit is portrayed as the great equalizer, a collective quality shared by all Harvard students, regardless of race, class, or gender. However, the statement also illustrates the central difficulty of operating with the concept of merit: If merit is conceptualized as innate ability-being "incredibly brilliant"-then selecting on the basis of merit would contradict many of the values Americans hold dear: hard work, dedication, discipline, self-improvement. But if merit is seen as achievement-having "worked incredibly hard"-it becomes impossible to deny or ignore its entanglement with socio-economic factors, as the Hunter 
College High School example demonstrates. The centrality of the topos of merit in the discourse of elite education and the cultural work in which it engages thus have to be scrutinized carefully. The uneasy relationship between merit and class in particular calls for close examination.

\section{Concluding Remarks}

In this chapter, I outlined in some detail the two guiding premises that informed my approach to the discourse of elite education: First, that there is a central tension between the American ideal of egalitarianism and the existence of a highly stratified educational system whose selection principles are all too often swayed by different forms of capital; and second, that the elite educational space works as a cultural signifier characterized by a semiotics of elite distinction whose meanings transcend academic education proper. I then introduced the three nodal points that I regard as central to the architecture of the discourse of elite education: eliteness, merit, and class. After addressing some defining features of the term 'elite'-its etymology, history of usage, and contemporary definitions-I laid out my own understanding of eliteness as a particularly productive concept in the field of cultural studies. Connoting privilege, wealth, and power as well as distinction, legitimacy, and skill, the concept of eliteness is more nuanced and flexible than semantically similar concepts and alludes to fantasies and desires, often distracting from its economic foundations. Despite its elusiveness, however, I have argued that the term commands a triad of relatively stable meanings: The first, and arguably most pervasive connotation is excellence/exceptionalism. An elite university is one that offers superior education to superior students, and boasts professors doing superior research. The second connotation the term elite holds is that of exclusivity/selectivity. By definition, elite institutions constitute only a small piece of the higher education pie, and they cater to an even smaller segment of the overall student population. Their exclusivity, measured in ever-decreasing admissions rates, is one of their primary assets, and the process of selection their applicants undergo one of their primary means of establishing legitimacy. Lastly, the notion of eliteness carries the connotation of influence/power. This refers on the one hand to the position of the institutions themselves, who are seen as leaders in the field of education, and on the other hand to the position of their graduates, who disproportionately populate leadership positions across all key sectors of the American society. 